\title{
Immune Checkpoint Inhibitors in Gynecological Cancers: Update of Literature and Perspectives of Clinical Research
}

\author{
ANGIOLO GADDUCCI and MARIA ELENA GUERRIERI \\ Department of Experimental and Clinical Medicine, \\ Division of Gynecology and Obstetrics University of Pisa, Pisa, Italy
}

\begin{abstract}
The presence of tumor infiltrating lymphocytes (TILs) influences the clinical outcome of cancer patients and immune checkpoint inhibitors (ICPI) have been approved for treating different types of malignancies. In this review, we assess the scanty data from literature and the perspectives of clinical research about the use of ICPI in gynecological cancers. These agents have obtained objective response rates ranging from $5.9 \%$ to $15 \%$ in early phase Ib-II trials, including patients with platinum-resistant ovarian cancer, whereas only anecdotal data are available for patients with recurrent, heavily pretreated endometrial cancer. Several ongoing trials are investigating ICPI alone or in combination with chemotherapy or with other biological agents in untreated and recurrent ovarian cancer, advanced and recurrent endometrial cancer, as well as advanced and recurrent cervical cancer. Breast cancer (BRCA)-mutated high-grade serous ovarian cancers, clear cell ovarian cancers with microsatellite instability (MSI), POLE ultramutated and MSI hypermutated endometrial cancers are likely to be sensitive to programmed cell death $(P D-1) / P D$ ligand $1(P D-L 1)$ pathway blockade, since these tumors show increased neoantigen load, increased $C D 8^{+}$TIL number and PD-1 and PD-L1 overexpression. ICPI could have a role as maintenance treatment in patients with persistent, recurrent or metastatic cervical cancer in response after chemotherapy.
\end{abstract}

This article is freely accessible online.

Correspondence to: Angiolo Gadducci, Department of Experimental and Clinical Medicine, Division of Gynecology and Obstetrics, University of Pisa, Via Roma 56, Pisa, 56127, Italy. Tel: +39 50992609, Fax: +39 50992354, e-mail: a.gadducci@med.unipi.it

Key Words: Immune checkpoint inhibitor, PD-1, PD-L1, CTLA, epithelial ovarian cancer, endometrial cancer, cervical cancer, review.
There is a large body of evidence supporting the crucial role of tumor immune microenvironment in carcinogenesis (1). The presence of tumor infiltrating lymphocytes (TILs) correlates with the clinical outcome of patients with different malignancies, such as melanoma, breast cancer, prostate cancer, renal cell cancer, esophageal cancer and colorectal cancer (2-8). The pooled analysis of 33 studies including several types of cancer revealed that high $\mathrm{CD}^{+}$TIL number, high $\mathrm{CD}^{+} \mathrm{TIL}$ number and high $\mathrm{CD} 8^{+} \mathrm{TIL} / / \mathrm{CD} 4^{+} \mathrm{CD} 25^{+} \mathrm{FoxP} 3^{+}$regulatory TIL (T-reg) ratio had a positive impact on overall survival (OS) with a hazard ratio (HR) of 0.58 (95\% confidence interval $(\mathrm{CI})=0.43-0.78), 0.71(95 \% \mathrm{CI}=0.62-0.82)$ and $0.48(95 \% \mathrm{CI}=$ 0.34-0.68), respectively (9). T-reg cells are a type of $\mathrm{CD}^{+}$ $\mathrm{T}$ cells that inhibit immune responses characterized by lack of expression of effector cytokines, such as interferon (IFN)- $\gamma$ and the production of inhibitory cytokines, such as transforming growth factor (TGF)- $\beta$, interleukin (IL)-10 and IL-35 (10). Beside T-reg cells and type-2 tumor-associated macrophages (TAM), the blockade of the T-cell response against tumor cells may be caused by immune checkpoint receptors expressed on the T-cell surface, such as cytotoxic T lymphocyte-antigen 4 (CTLA-4) and programmed cell death (PD-1) receptor (10-14). CTLA4 counteracts the activity of the T cell co-stimulatory receptor $\mathrm{CD} 28$ for binding to the ligands B7.1 and B7.2 expressed on antigen-presenting cells and, therefore, CTL4 functions as a negative immune regulator. Similarly, the linkage between PD-1 on $\mathrm{T}$ cells and the programmed-death ligand (PD-L1) on tumor cell surface inhibits T-cell proliferation and increases T-reg cell number, thus resulting in Tcell function inhibition (11-14). Whereas CTLA-4 predominately regulates T cell activation within secondary lymphoid organs, PD-1 regulates $\mathrm{T}$ cell function within peripheral tissues and tumor microenvironment $(10,12,15)$.

Monoclonal antibodies (mAbs) targetingPD-1 (i.e. pembro-lizumab and nivolumab) and PD-L1 (i.e. avelumab, atezolizumab and durvalumab), as well as mAbs targeting CTLA-4 (ipilimumab and tremelimumab), have been 
approved by Food and Drug Administration (FDA) for several malignancies, such as melanoma, non-small cell lung cancer, renal cell cancer, urothelial cancer and lymphoma (16-20). Anti-CTLA mAbs and anti-PD-1/PD-L1 mAbs cause immune-related adverse events (AEs) in $60 \%$ and $40 \%$ of cases, respectively, but severe AEs are more frequent with anti-CTLA therapy $(21,22)$. The management of these AEs depends on their severity and ranges from immune checkpoint inhibitor therapy suspensionto the administration of corticosteroids and, also, to the use of anti-tumor necrosis factor (TNF)- $\alpha$ mAbs, mycophenylate mofetil, tacrolimus and cyclosporine (23).

Four distinct patterns of response to immune checkpoint inhibition have been observed: (i) regression of baseline lesions; (ii) stable disease followed by a slow decline in tumor burden; (iii) delayed response after an initial increase in tumor burden; and (iv) response after the appearance of new lesions (24). The three latter patterns of response havenot been reportedwith chemotherapeutic agents (25). Novel immunerelated response criteria, different from the Response Evaluation Criteria in Solid Tumors (RECIST) 1.1 and modified World Health Organization (WHO) criteria (24), have been suggested for immune checkpoint inhibitors $(25,26)$.

Tumors can be classified into four groups based on PDL1 expression and $\mathrm{T}$ cell infiltration (27). Type I tumors (PD-L1-positive, TILs+) exhibit an adaptive immune resistance and are likely to respond to immune checkpoint inhibitors, whereas type II tumors (PD-L1-negative, TILs ${ }^{-}$) display no detectable immune reaction and are likely to be unresponsive to single- agent checkpoint blockade. Type III tumors (PD-L1-positive, TILs ${ }^{-}$) exhibit intrinsic expression of PD-L1 with no immune reactivity, which suggests that PD-L itself is not apredictive biomarker of response to antiPD-1/PD-L1 mAbs. Type IV tumors (PD-L1-negative, TILs+) may be amenable to targeting of other non-PD-1/PDL1 checkpoint receptors.

The present manuscript reviews the few data availablein literature on the use of immune checkpoint inhibitors in the management of gynecological cancers.

\section{Epithelial Ovarian Cancer}

The number and type of TILs influence the clinical outcome of patients with epithelial ovarian cancer (EOC) (28-33). For instance, in the study of Zhang et al. (28), the presence of TILs was detected in $54.8 \%$ of 186 frozen specimens from women with this malignancy and found to be correlated with increased expression of IFN- $\gamma$, IL-2 and 1ymphocyteattracting chemokines within the tumor. Median progressionfree survival (PFS) and median OS were 22.4 months and 50.3 months, respectively, for patients whose tumors contained TILs versus 5.8 months and 18.0 months for those whose tumors did not contain TILs ( $p<0.001$ for both). The meta-analysis of 10 studies, including 1,815 patients with EOC, confirmed that lack of intraepithelial TILs correlated with worse OS (pooled HR=2.24, 95\% CI=1.71-2.91) (29).

High $\mathrm{CD}^{+} \mathrm{T}$ cell infiltration was an independent favorable prognostic factor in a series of 203 patients with EOC: the mortality risk decreased by $18 \%$ with each doubling of $\mathrm{CD}^{+} \mathrm{T}$ cell density $(\mathrm{HR}=0.82,95 \% \mathrm{CI}=0.73$ 0.92) (33). The immunohistochemical analysis of paraffinembedded specimens from 117 women with EOC showed that patients with higher frequencies of intraepithelial $\mathrm{CD}^{+}$ $\mathrm{T}$ cells had a better clinical outcome compared with those with lower frequencies (median $\mathrm{OS}=55$ versus 26 months, $\mathrm{HR}=0.33,95 \% \mathrm{CI}=0.18-0.60)(31)$. It is noteworthy that median OS was 57.6 months for patients with high $\mathrm{CD}^{+} \mathrm{T}$ cell/T-reg cell ratios versus 22.6 months for those with low ratios $(\mathrm{HR}=0.31,95 \% \mathrm{CI}=0.17-0.58)$.

Hamanishi et al. (34) found strong immunostaining for PD-L1 in $68.5 \%$ of tissue samples from 70 patients with EOC. There was a significant inverse correlation between intraepithelial $\mathrm{CD}^{+} \mathrm{T}$ cell count and PD-L1 expression, thus suggesting that PD-L1 on tumor cells could block the intraepithelial invasion of tumor-specific $\mathrm{CD}^{+} \mathrm{T}$ cells.

Conflicting data emerge from the literature about the prognostic relevance of PD-1 and PD-L1 expression in EOC and these discordant results may reflect different techniques for PD-1 and PD-L1 assessment, different cut-off values for tumor cell staining, as well aspatients' heterogeneity (34-38).

PD-1/PD-L1 blockade caused tumor regression in a syngeneic EOC mouse model, thus supporting the relevance of this regulatory pathway in ovarian carcinogenesis (38).

Some phase Ib-II trials have investigated the activity and safety of anti-PD1 or anti-PD-L1 mAbs in platinum-resistant EOC, with objective response (OR) (complete response (CR)+ partial response (PR)) rates ranging from $5.9 \%$ to $15 \%$ (22, $39-41$ ) and with grade $(\mathrm{G}) \geq 3 \mathrm{AE}$ rates ranging from $3.8 \%$ to $40 \%$ (Table I). Nivolumab obtained an OR and a disease control (CR+PR+stable disease (SD)) in $15 \%$ and $45 \%$ of 20 patients who had received at least two prior chemotherapy lines (39) (Table I). Immunohistochemical expression of PDL1 was high in 16 patients $(80 \%)$ and low in $4(20 \%)$; however, this variable did not correlate with OR rate.

Varga et al. (40) reported an OR rate of $11.5 \%$ and a disease control rate of $34.6 \%$ in 26 women with PD-L1-positive advanced EOC treated with pembrolizumab (Table I). Eightyfive per cent of the patients had received prior therapies for recurrent/metastatic disease, whereas $38.5 \%$ had received five or more therapies.

Avelumab achieved an OR in $9.7 \%$ and a disease control in $54.0 \%$ of 124 women with recurrent or refractory EOC (41) (Table I). PD-L1 expression was evaluable in 74 cases. Using a $\geq 1 \%$ cut-off for tumor cell staining, 57 women (77.0\%) were PD-L1+, with OR rate being $12.3 \%$ in PD-L1positive versus $5.9 \%$ in PD-L1-negative patients. 
Table I. Phase I-II studies of anti-programmed cell death (PD)1 or anti-programmed cell death ligand (PD-L)1 antibodies in platinum-resistant epithelial ovarian cancer.

\begin{tabular}{|c|c|c|c|c|c|c|c|c|}
\hline \multirow[t]{2}{*}{ Reference } & \multirow[t]{2}{*}{ Agent } & \multirow[t]{2}{*}{ Patients } & \multirow[t]{2}{*}{$\mathrm{CR}$} & \multirow[t]{2}{*}{ PR } & \multirow[t]{2}{*}{ OR } & \multirow[t]{2}{*}{ SD } & \multicolumn{2}{|c|}{ AEs } \\
\hline & & & & & & & Any $G$ & $\mathrm{G} \geq 3$ \\
\hline 39 & $\begin{array}{c}\text { Nivolumab } \\
1 \text { or } 3 \mathrm{mg} / \mathrm{kg} \mathrm{q} 14\end{array}$ & 20 & 2 & 1 & $\begin{array}{c}3 \\
(15 \%)\end{array}$ & $\begin{array}{c}6 \\
(30 \%)\end{array}$ & $\begin{array}{c}19^{\wedge} \\
(95 \%) \\
(40 \%)\end{array}$ & 8 \\
\hline 40 & $\begin{array}{l}\text { Pembrolizumab } \\
10 \mathrm{mg} / \mathrm{kg} \mathrm{q} 14\end{array}$ & 26 & 1 & 2 & $\begin{array}{c}3 \\
(11.5 \%)\end{array}$ & $\begin{array}{c}6 \\
(23.1 \%)\end{array}$ & $\begin{array}{c}18^{\wedge \wedge} \\
(69.2 \%)\end{array}$ & $\begin{array}{c}1 \\
(3.8 \%)\end{array}$ \\
\hline 41 & $\begin{array}{c}\text { Avelumab } \\
10 \mathrm{mg} / \mathrm{kg} \mathrm{q} 14\end{array}$ & 124 & 0 & 12 & $\begin{array}{c}12 \\
(9.7 \%)\end{array}$ & $\begin{array}{c}55 \\
(44.3 \%)\end{array}$ & $\begin{array}{c}82+ \\
(66.1 \%)\end{array}$ & $\begin{array}{c}8 \\
(6.5 \%)\end{array}$ \\
\hline 22 & $\begin{array}{c}\text { BMS-936559 } \\
0.3-10 \mathrm{mg} / \mathrm{kg} \mathrm{q} 14\end{array}$ & 17 & 0 & 1 & $\begin{array}{c}1 \\
(5.9 \%)\end{array}$ & $\begin{array}{c}3 \\
(17.6 \%)\end{array}$ & $\begin{array}{c}81++/ 207^{\circ} \\
(39.1 \%)\end{array}$ & $\begin{array}{l}10 / 207^{\circ} \\
(4.8 \%)\end{array}$ \\
\hline
\end{tabular}

${ }^{\wedge}$ Most common: increased serum transaminases, hypothyroidism, lymphocytopenia, decreased serum albumin, fever, rash, arthralgia, arrhythmia, fatigue, anemia; $\wedge \wedge$ Most common: fatigue,anemia, decreased appetite; +Most common: fatigue, infusion reactions, diarrhea; ++Most common: fatigue, infusion reactions, diarrhea, arthralgia, rash, nausea, pruritus, headache; ${ }^{\circ}$ toxicity was evaluated on the total of the 207 patients included in the study (75 with non-small-cell lung cancer, 55 with melanoma, 18 with colorectal cancer, 17 with renal-cell cancer, 17 with ovarian cancer, 14 with pancreatic cancer, 7 with gastric cancer and 4 with breast cancer. CR, Complete response; PR, partial response; OR, objective response; SD, stable disease; AEs, adverse events; G, grade.

In a phase I trial, Brahmer et al. (22) administered the anti-PD-L1 mAbBMS-936559 to 207 patients with selected advanced cancers (Table I). Among the 17 women with EOC, $1(5.9 \%)$ had a PR and $4(23.5 \%)$ had a disease control, all at the 10-mg dose.

Combining the nivolumab and avelumab studies, it has been observed that 4 of the 5 patients who experienced durable responses had clear cell EOC (CCOC), which is a chemoresistant histologic type. Alterations of the phosphatidylinositol 3-kinase (PIK3CA)/AKT/mammalian target of rapamycin (mTOR) pathway have been detected in 15\%-75\% of CCOCs (42-49) and preclinical data from non-small cell lung cancer have suggested that activation of this pathway correlates with an increased expression of PD-L1 in tumor cells (50).

The administration of ipilimumab after vaccination with irradiated, autologous tumor cells engineered to secrete granulocyte-macrophage colony-stimulating factor showed antitumor effects also in patients with stage IV EOC (51). In a phase II study, 40 patients with recurrent platinum-sensitive EOC were scheduled to receive ipilimumab $(10 \mathrm{mg} / \mathrm{kg})$ every 3 weeks for 4 cycles (induction phase) followed by ipilimumab $(10 \mathrm{mg} / \mathrm{kg})$ every 12 weeks until progression or unacceptable toxicity (52). Thirty-eight patients (95\%) did not complete the induction phase, mainly because of progression or toxicity. The OR rate was $10.3 \%$ and $\mathrm{G} \geq 3$ AEs occurred in $50 \%$ of the patients.

Table II shows the ongoing trials of checkpoint inhibitors alone or in combination with chemotherapy in EOC.

Immune checkpoint inhibitors have demonstrated remarkable activity against hypermutated cancers, such as melanoma and lung cancer, and against tumors with mismatch repair $(M R R)$ gene alterations, such as colon cancer, which harbor more tumor-specific neoantigens (53-56). This higher antigen load enhances the recruitment of an increased number of TILs, which is counterbalanced by PD-1 or PD-L1 overexpression. Strickland et al. (57) subdivided 245 tumor samples from patients with HGSOC in three groups: BRCAl2 mutated ( $\mathrm{n}=54)$, wild-type (wt)-BRCAl-2 with homologous recombination $(H R)$ deficiency (HRD) $(\mathrm{n}=69)$ and wtBRCA1-2 without HRD (HR-proficient tumors).Wt-BRCAl2 with $H R D$ tumors harbored mutations in several HR genes, such as Fanconi anemia, RAD50, RAD51, RAD54L, ATM and $A T R$, tensin homolog deleted on chromosome (PTEN) deletion, EMSY amplification or mutation and promoter hypermethylation of BRCAI or RAD51C. Neoantigen load was higher in the $B R C A 1-2$ mutated subset compared with HR-proficient subset $(p=0.008)$, as well as in wt-BRCA1-2 with HRD cohort compared with HR-proficient cohort $(p=0.003)$. Moreover, BRCA1-2 mutated tumors showed a significantly increased $\mathrm{CD}^{+}$and $\mathrm{CD}^{+}$TIL number anda significantly higher expression of PD-1 and PD-L1 compared with HR-proficient tumors. Therefore, BRCA1-2-mutated HGSOCs could represent a subset of tumors fit for treatment with immune checkpoint inhibitors alone or in combination with poly(adenosine diphosphate (ATP-ribose) polymerases (PARP) inhibitors (57-59). Moreover, Strickland et al. (60) found that 3 out of 30 (10\%) CCOCs exhibited microsatellite instability (MSI) and that CCOCs with MSI had a higher number of $\mathrm{CD}^{+}$TILs and higher number of PD1-positive TILs compared with both microsatellite stable (MSS) CCOCs 
Table II. Ongoing trials of checkpoint inhibitors alone or in combination with chemotherapy in epithelial ovarian cancer.

\begin{tabular}{lcc}
\hline Study number & Study phase & Study design \\
\hline NCT02498600 & 2 & $\begin{array}{c}\text { Nivolumab with or without ipilimumab in treating patients with } \\
\text { persistent or recurrent EOC, PPC or FTC }\end{array}$ \\
$\begin{array}{l}\text { NCT02718417 } \\
\text { JAVELIN } \\
\text { OVARIAN 100 }\end{array}$ & 3 & $\begin{array}{c}\text { Avelumab in previously untreated patients with EOC. } \\
\text { NCT02580058 }\end{array}$ \\
JAVELIN OVARIAN 200 & 3 & $\begin{array}{c}\text { This is apen-label, efficacy and safety study of avelumab in combination } \\
\text { with and/or following platinum-based chemotherapy. }\end{array}$ \\
\hline
\end{tabular}

EOC, Epithelial ovarian cancer; PPC, primary peritoneal cancer; FTC, fallopian tube cancer; PLD, pegylated liposomal doxorubicin.

and HGSOCs. Therefore, CCOCs with MSI may represent an immunogenic subset of tumors likely to respond to anti-PD1/PD-L1 mAbs.

Several phase I-II studies are currently testing immune checkpoint inhibitors in combination with other biological agents, such as PARP inhibitors or anti-angiogenic agents, in patients with recurrent EOC.

The NCT02571725 trial will assess the side-effects and best dose of tremelimumab when given together with the PARP inhibitor olaparibin patients with recurrent platinumsensitive or platinum-resistant EOC, fallopian tube cancer (FTC) or primary peritoneal cancer (PPC) and germline BRCA1 or BRCA2 mutation.

The NCT02734004 trial will evaluate the safety, tolerability, pharmacokinetics and antitumor activity of durvalumab in combination with olaparib in patients with different advanced solid tumors, including those with recurrent platinum-sensitive EOC and germline BRCA mutation.

The NCT02953457 trial will study the side-effects and best dose of olaparib when given together with durvalumab and tremelimumab, as well as the activity of this combination in treating patients with recurrent platinum-sensitive or -resistant or -refractory EOC, FTC or PPC and germline or somatic $B R C A 1$ or BRCA2 mutation.

The NCT02484404 study will test the safety and activity of durvalumab in combination with olaparib and/or the vascular endothelial growth factor (VEGF) receptor inhibitor cediranib in patients with different advanced solid tumors, including those with recurrent platinum-sensitive, -resistant or -refractory EOC, FTC or PPC and germline BRCAl or BRCA2 mutation.

NCT02657889 will assess the safety and efficacy of combination treatment with the PARP inhibitor niraparib and pembrolizumab in patients with triple-negative breast cancer who have received $\leq 3$ lines of prior chemotherapy in the metastatic setting or with recurrent, platinum-resistant EOC who have received $\leq 4$ lines of prior chemotherapy for advanced disease.

\section{Endometrial Cancer}

The dualistic model for endometrial cancer (EC) subdivides this malignancy in two main categories: type-I estrogendependent endometrioid carcinomas and type-II estrogenindependent non-endometrioid carcinomas (61-63). Major molecular alterations of type-I carcinomas include PTEN silencing, PIK3CA mutations, $M M R$ defects, $M S I$ and $K$-RAS or $\beta$-catenin $(C T N N B)$ mutations, whereas type IIcarcinomas often show $p 53$ mutations, $p 16$ inactivation, low E-cadherin expression, Her-2/neu overexpression, STK15 amplification and loss of heterozygosity (LOH) on several chromosomes (62-67).

The loss of PTEN function with consequent activation of PIK3CA/AKT/mTOR pathway is an early and common event in the pathogenesis of endometrioid carcinomas, occurring approximately up to $80 \%$ of these malignancies and $55 \%$ of endometrial hyperplasias $(68,69)$. Beta-catenin mutations with nuclear protein accumulation, $M S I$, and $K$ $R A S$ mutations have been detected in $25 \%$ to $38 \%, 25 \%$ to $35 \%$ and $10 \%$ to $30 \%$ of endometrioid carcinomas, respectively $(62,63,68-70)$. Whereas $M S I, P T E N$ alterations or $K-R A S$ mutations may coexist in many cases, these molecular abnormalities are not usually associated with $\beta$ catenin mutations. However, this dualistic model does not take into account the molecular, biological and pathological heterogeneity among each category and recently a novel classification system has been proposed by The Cancer Genome Atlas Research Network (TCGA) (71, 72). The integrated genomic, transcriptomic and proteomic characterization of 373 ECs using array- and sequencingbased technologies has suggested to classify these malignancies into four categories: polymerase $\varepsilon$ (POLE) ultramutated, MSI hypermutated, copy number low (endometrioid) and copy number high (serous-like).

POLE is a catalytic subunit of DNA polymerase involved in DNA replication, DNA repair and cell cycle control (73). POLE ultramutated tumors display very high mutation rates 
$\left(232 \times 10^{-6}\right.$ mutations $\left./ \mathrm{Mb}\right)$ and are characterized by hotspot mutations in the exonuclease domain of POLE, high frequency of base substitutions and large excess of cytosine $\rightarrow$ adenine transversions, elevated incidence of PTEN, PIK3CA, FBXW7 and $K$-RAS mutations, strong association with endometrioid histology and MSS $(71,72,74)$. Although $p 53$ mutations can be detected in approximately one third of the cases, it is important not to misclassify these tumors as serous carcinomas (75). Tumor grade ranges from 1 to 3 but more frequently is 3 , with prognosis beingexcellent also in cases with high histological grade (75-79). POLE mutations were detected in $6.1 \%$ of 788 ECs enrolled in PORTEC-1 and-2 randomized trials. Women with POLE-mutant ECs had fewer relapses (6.2\% versus $14.1 \%)$ and tumor-related deaths $(2.3 \%$ versus $9.7 \%$ ) (76). It is noteworthy that among the 109 grade 3 tumors, disease relapsed in none of 15 POLE-mutant carcinomas versus $30.9 \%$ of 94 POLE wild-type carcinomas. Meng et al. (77) identified POLE mutations in $15 \%$ of 53 grade 3 endometrioid carcinomas compared with $0 \%$ of 25 serous carcinomas, $0 \%$ of 16 clear cell carcinomas and $0 \%$ of 5 de-differentiated carcinomas. None of the patients with POLE mutated tumors in this study (77), as well as in the study of Hussein et al. (75), developed recurrent disease. McCornery et al. (79) detected POLE mutations in $9.6 \%$ of 406 ECs. $P O L E$-mutated women were younger and frequently had stage I disease (92\%), tumor grade $3(62 \%)$, endometrioid histology (82\%) and lymphovascular space involvement (LVSI) (49\%). POLE mutation was an independent favorable prognostic variable for PFS $(\mathrm{HR}=0.34,95 \% \mathrm{CI}=0.15-0.73)$ and disease-specific survival (DSS) $(\mathrm{HR}=0.35,95 \% \mathrm{CI}=0.13-0.92)$.

MSI hypermutated ECs show high mutation rates $\left(18 \times 10^{-6}\right.$ mutations/Mb), recurrent RPL22 frameshift deletions, frequent PTEN and $K-R A S$ mutations, as well asendometriod histology $(71,72)$. Tumor grade ranges from 1 to 3, with prognosis beingusually good but less favorable than that of POLE ultramutated EC (intermediate prognosis). Alterations of $M M R$ genes are involved in the pathogenesis of the hypermutated tumors.

Copy number low ECs include MSS grade 1-2 endometrioid tumors with low mutation rates $\left(2.9 \times 10^{-6}\right.$ mutations/Mb), frequent PTEN, PI3KCA and $\beta$-catenin $(C T N N B)$ mutations and intermediate prognosis, whereas copy number high (serous-like) ECs show extensive copy number aberrations, low mutation rates $\left(2.3 \times 10^{-6}\right.$ mutations $\left./ \mathrm{Mb}\right)$, very frequent $p 53$ mutations and MSS $(71,72)$. Histological type can be serous, grade 3 endometrioid, as well asmixed, serous and endometrioid, with poor prognosis.

The immune system plays an important role both in the physiological changes of endometrium and inendometrial carcinogenesis $(80,81)$. de Jong et al. $(82)$ assessed CD8 ${ }^{+}$ TILs and T-reg cells on paraffin-embedded tissue specimens from 368 patients with Fédération Internationale de Gynécologie et d'Obstétrique (FIGO) stage I-IV EC. A high number of $\mathrm{CD}^{+} \mathrm{T}$ cells and/or a high $\mathrm{CD} 8^{+} \mathrm{T}$ cell $/ \mathrm{T}$-reg cell ratio correlated with early stage, low histologic grade, superficial myometrial invasion, lack of LVSI, negative lymph nodes and absence of distant metastases at the time of diagnosis. A high number of $\mathrm{CD}^{+} \mathrm{T}$ cells was an independent favorable prognostic variable for OS in the entire cohort $(\mathrm{HR}=0.48,95 \% \mathrm{CI}=0.26-0.89)$ and in type II ECs $(\mathrm{HR}=0.17,95 \% \mathrm{CI}=0.08-0.36)$, whereas a high $\mathrm{CD}^{+} \mathrm{T}$ cell/T-reg cell ratio was an independent good prognostic factor for OS in type I ECs $(\mathrm{HR}=0.44,95 \% \mathrm{CI}=0.23-0.84)$. The analysis of paraffin-embedded specimens from 53 women with EC revealed thatT-reg cell count and T-reg cell/CD8 ${ }^{+} \mathrm{T}$ cell ratios were significantly higher in patients with advanced, poorly differentiated carcinomas and with LVSI than in those with early, well-differentiated carcinomas and without LVSI (83). Disease-free survival (DFS) of patients with high T-reg cell count and high T-reg cell/CD8 ${ }^{+}$ $\mathrm{T}$ cell ratio was significantly worse than that of patients with low T-reg cell count and low T-reg cell/CD8 ${ }^{+} \mathrm{T}$ cell ratio.

PD-1 and PD-L1 have been detected in EC tissues (84, $85)$. The immunohistochemical analysis of tumor samples from 301 ECs showed positive immunostaining for PD-1 and PD-L1 in $77.9 \%$ and $39.7 \%$, respectively, of endometrioid carcinomas, $68.2 \%$ and $10.2 \%$ of serous carcinomas, $69.2 \%$ and $23.1 \%$ of clear cell carcinomas and $80.0 \%$ and $22.2 \%$ of carcinosarcomas (84).

Howitt et al. (86), who assessed tumor specimens from 63 patients with EC, found that median neoantigen load per sample was 8,342 (range $=628-20,440$ ) in POLE ultramutated tumors, 541 (range $=146-8,063, p<0.001$ ) in MSI hypermutated tumors and 70.5 (range $=7-1,877, p<0.001$ ) in MSS tumors. Similarly, POLE ultramutated and MSI hypermutated ECs had significantly higher numbers of $\mathrm{CD}^{+}$TILs and $\mathrm{CD}^{+}$TILs compared with MSS ECs; this high immunogenicity could be an explanation of their favorable prognosis. Moreover, PD-1 was overexpressed in TILs and peritumoral lymphocytes of POLE and MSI tumors, whereas PD-L1 expression was infrequent in tumor cells but common in intraepithelial immune cells, especially in POLE and MSI tumors. Therefore, POLE ultramutated and MSI hypermutated ECs show high neoantigen load and high number of TILs, counterbalanced by PD-1 and PD-L1 overexpression. Such features could represent a strong rationale for testing immune checkpoint inhibitors in these cancer subgroups (86-88).

Santin et al. (89) reported a remarkable clinical response to nivolumab intwo patients with recurrent, heavily pretreated ultramutated or hypermutated endometrial cancer.

The ongoing trials of checkpoint inhibitors in EC are shown in the Table III. In the NCT02630823 trial, the mechanism of action of pembrolizumab on tumor environment will be investigated by examining both pretreatment endometrial biopsy and the definite surgical specimen after two cycles of pembrolizumab. 
Table III. Ongoing trials of checkpoint inhibitors in endometrial cancer and cervical cancer.

\begin{tabular}{|c|c|c|}
\hline Study number & Study phase & Study design \\
\hline NCT02549209 & 2 & $\begin{array}{l}\text { Pembro/carbo/taxol in endometrial cancer (EC) } \\
\text { This is a single-arm, open-label study for women with measurable advanced/recurrent } \\
\text { EC using pembrolizumab in combination with CBDCA+TAX chemotherapy. }\end{array}$ \\
\hline NCT02630823 & 1 & $\begin{array}{l}\text { MK-3475 (pembrolizumab) immunotherapy in EC } \\
\text { Patients with grade3 endometrioid, serous, clear cell or mixed high-grade EC } \\
\text { will undergo endometrial biopsy followed by } 2 \text { cycles of pembrolizumab ( } 3 \text { weeks apart). } \\
\text { Then the standard of care surgical resection will take place followed by standard of } \\
\text { care adjuvant therapy. The standard chemotherapy will consist of CBDCA+TAX } \\
\text { q21 for } 6 \text { cycles. The decision to administer radiotherapy will be per the treating } \\
\text { physician. For patients with high-risk features and advanced stage, pembrolizumab will } \\
\text { be given q21 after completion of adjuvant therapy for a maximum of } 4 \text { doses post-surgery. }\end{array}$ \\
\hline NCT02257528 & 2 & A phase II evaluation of nivolumab in the treatment of persistent or recurrent CC \\
\hline NCT01693783 & 2 & $\begin{array}{c}\text { Ipilimumab in treating patients with metastatic or recurrent HPV-related CC of } \\
\text { either squamous cell or adenocarcinoma histologies }\end{array}$ \\
\hline NCT01711515 & 1 & $\begin{array}{l}\text { Chemoradiation therapy and ipilimumab in treating patients } \\
\text { with stages IB2-IIB or IIIB-IVA CC }\end{array}$ \\
\hline NCT02488759 & $1-2$ & $\begin{array}{l}\text { Non-comparative, open-label, multiple cohort, phase } 1-2 \text { study of nivolumab monotherapy and } \\
\text { nivolumab combination therapy in patients with virus-positive and virus-negative solid tumors }\end{array}$ \\
\hline
\end{tabular}

EC, Endometrial cancer; CBDCA, carboplatin; TAX, paclitaxel; CC, cervical cancer; HPV, human papilloma virus.

\section{Cervical Cancer}

The goal of treatment of women with recurrent, persistent or metastatic cervical cancer (CC) not amenable to surgery or radiotherapy is palliation of symptoms and prolongation of survival and the combination of paclitaxel (TAX) + cisplatin (CDDP) has been long considered as the standard of care (90). The Gynecologic Oncology Group (GOG) 240 phase III trials randomized 452 patients with stage IVB, recurrent or persistent $\mathrm{CC}$ to receive combination chemotherapy with TAX + CDDP (every 3 weeks) or topotecan + TAX (every 3) weeks with or without bevacizumab (BEV) $(15 \mathrm{mg} / \mathrm{kg}$ every 3 weeks) (91). Topotecan + TAX showed a significantly higher risk of progression and a trend to a higher risk of death when compared with CDDP + TAX either with or without $\mathrm{BEV}$. With the data for the two regimens combined together, the addition of BEV significantly improved median PFS (8.2 versus 5.9 months; $\mathrm{HR}=0.67,95 \% \mathrm{CI}=0.54-0.82)$ and median OS (17.0 versus 13.3 months; $\mathrm{HR}=0.71,95 \% \mathrm{CI}=0.54-0.95)$ compared with chemotherapy alone.

The treatment after platinum failure is a big challenge and the currently available single-agents, such as topotecan (92), vinorelbine (93), gemcitabine (94), pemetrexed (95), capecitabine (96), docetaxel (97) and nab-paclitaxel (98), have shown unsatisfactory activity. Therefore, the assessment of novel drugs, such as immunecheckpointinhibitors, is strongly warranted in this clinical setting (99-102).

Both PD-1 and PD-L1 have been detected in CC tissues (101, 103-106). Heeren et al. (106) assessed PD-L1 expression in tumor specimens from two cohorts of $\mathrm{CC}$ patients: primary tumor samples from cohort I (squamous cell carcinoma (SCC), $n=156$ and adenocarcinoma (AD), $\mathrm{n}=49$ ) and primary and paired metastatic tumor samples from cohort II ( $\mathrm{SCC}, \mathrm{n}=96$ and $\mathrm{AD}, \mathrm{n}=31$ ). $\mathrm{PD}-\mathrm{L} 1$ positivity was observed in $>5 \%$ of the tumor cells in $54 \%$ of SCCs and in $14 \%$ of ADs $(p<0.001)$, PD-L1-positive TAMs were present in $53 \%$ of the former and $12 \%$ of the latter $(p<0.001)$ displaying an M2-like phenotype characterized by protumorigenic properties (107). DFS and DSS were significantly poorer in SCC patients with diffuse PD-L1 expression than in those with marginal PD-L1 expression in primary tumors ( $p=0.022$ and $p=0.046$, respectively). Moreover, DSS was worse in AD patients with PD-L1positive TAMs than in those without PD-L1-positive TAMs $(p=0.014)$.

More dense cordons of PD-L1-positive immune cells were found surrounding the metastases compared with the paired primary tumors in both SCC and AD. These findings appear to provide a rationale for therapeutic targeting of the PD1/PD-L1 pathway in CC.

Several phase I-II trials are currently testing immune checkpoint inhibitors in $\mathrm{CC}$ but no results have been releasedyet (Table III).

In the NCT02257528 trial,immune infiltration-related biomarkers (i.e., CD4+T, CD8 ${ }^{+} \mathrm{T}$, T-reg) in tumor specimens and PD-1 and PD-L1 expression in TILs and CC cells will be related to OR, PFS and OS of patients with persistent, recurrent or metastatic $\mathrm{CC}$ treated with nivolumab. 
NCT02488759 is a phase 1-2 study investigating the safety and efficacy of nivolumab alone andin combination with ipilimumab or BMS-986016 anti- lymphocyte activation gene-3 (LAG-3) mAb or daratumumab (anti-CD38 $\mathrm{mAb}$ ) in patients with different tumors, including squamous cell carcinoma of the cervix, vagina, or vulva.

Longoria and Tewari (100) have proposed a clinical trial of combined anti-angiogenic therapy and immunotherapy in metastatic, recurrent or persistent CC. Patients with evidence of response and no unacceptable toxicity after combination chemotherapy (CDDP+TAX or carboplatin+TAX or topotecan+ TAX) plus BEV (15 mg/kg every 3 weeks) for 7 cycles will be randomly allocated to receive either chemotherapy +BEV + nivolumab $(3 \mathrm{mg} / \mathrm{kg})$ every 3 weeks or chemotherapy + BEV + placebo every 3 weeks until progression or unacceptable toxicity.

\section{Conclusion}

Very limited data are currently available about the activity of immune checkpoint inhibitors in gynecological cancers; however, immune checkpoint inhibitors, and especially antiPD-1 and anti-PD-L1 mAbs, could represent a novel pharmacological tool for the management of gynecological malignancies, although is yet to be defined which patients could draw a greater clinical benefit from these agents and when immunecheckpointinhibitors should be incorporated into the therapeutic strategy $(37,108,109)$. Moreover, reliable biomarkers predictive of response have not been identified yet

BRCA1-2-mutated HGSOC and CCOC with MSI could have an elevated probability of response to these agents because these tumors show increased neoantigen load, increased $\mathrm{CD}^{+}$and $\mathrm{CD}^{+}$TIL number, as well as PD-1 and PD-L1 overexpression. Immune checkpoint inhibitors in combination with PARP inhibitors are currently investigated in patients with recurrent EOC and mutated BRCA1-2.

As far as EC is concerned, POLE ultramutated tumors have a median number of neo-antigensalmost 15 -fold higher than MSI hypermutated tumors,with the latter having a median number of neo-antigens 7-fold higher than MSS tumors. POLE ultramutated and MSI hypermutated ECs exhibit a high number of TILs counter balanced by PD-1 and PD-L1 overexpression and, therefore, they are likely to be sensitive to PD-1/PD-L1 pathway blockade. Immune check-point inhibitors could have a role as maintenance treatment in patients with persistent, recurrent or metastatic $\mathrm{CC}$ in response after chemotherapy.

\section{References}

1 Llosa NJ, Cruise M, Tam A, Wicks EC, Hechenbleikner EM, Taube JM, Blosser R, Fan H, Wang H, Luber BS, Zhang M, Papadopoulos N, Kinzler KW, Vogelstein B, Sears CL, Anders RA, Pardoll DM and Housseau F: The vigorous immune microenvironment of microsatellite instable colon cancer is balanced by multiple counter-inhibitory checkpoints. Cancer Discov 5: 43-51, 2009.

2 Vesalainen S, Lipponen P, Talja M and Syrjanen K: Histological grade, perineural infiltration, tumour-infiltrating lymphocytes and apoptosis as determinants of long-term prognosis in prostatic adenocarcinoma. Eur J Cancer 30: 1797-1803,1994.

3 Marrogi AJ, Munshi A, Merogi AJ, Ohadike Y, El-Habashi A, Marrogi OL and Freeman SM: Study of tumor infiltrating lymphocytes and transforming growth factor-beta as prognostic factors in breast carcinoma. Int J Cancer 74: 492- 501,1997.

4 Halpern AC and Schuchter LM: Prognostic models in melanoma. Semin Oncol 24(Suppl 4): S2-S7,1997.

5 Naito Y, Saito K, Shiiba K, Ohuchi A, Saigenji K, Nagura H and Ohtani H: CD8+ T cells infiltrated within cancer cell nests as a prognostic factor in human colorectal cancer. Cancer Res 58: 3491-3494,1998.

6 Nakano O, Sato M, Naito Y, Suzuki K, Orikasa S, Aizawa M, Suzuki Y, Shintaku I, Nagura H and Ohtani H: Proliferative activity of intratumoral CD8(+) T-lymphocytes as a prognostic factor in human renal cell carcinoma: clinicopathologic demonstration of antitumor immunity. Cancer Res 61: 51325136, 2001.

7 Schumacher K, Haensch W, Roefzaad C and Schlag PM: Prognostic significance of activated CD8(+) T cell infiltrations within esophageal carcinomas. Cancer Res 61: 3932-3936, 2001.

8 Mittal D, Gubin MM, Schreiber RD and Smyth MJ: New insights into cancer immunoediting and its three component phases - elimination, equilibrium and escape. Curr Opin Immunol 27: 16-25, 2014.

9 Gooden MJ, de Bock GH, Leffers N, Daemen T and Nijman HW: The prognostic influence of tumour-infiltrating lymphocytes in cancer: a systematic review with meta-analysis. Br J Cancer 105: 93-103, 2011.

10 Pardoll DM: The blockade of immune checkpoints in cancer immunotherapy. Nat Rev Cancer 12: 252-64, 2012.

11 Chen DS and Mellman I: Oncology meets immunology: the cancer-immunity cycle. Immunity 39: 1-10, 2013.

12 Freeman GJ, Long AJ, Iwai Y, Bourque K, Chernova T, Nishimura H, Fitz LJ, Malenkovich N, Okazaki T, Byrne MC, Horton HF, Fouser L, Carter L, Ling V and Bowman MR: Engagement of the PD-1 immunoinhibitory receptor by a novel B7 family member leads to negative regulation of lymphocyte activation. J. Exp. Med 192: 1027-1034, 2000.

13 Keir ME, Francisco LM and Sharpe AH: PD-1 and its ligands in T-cell immunity. Curr Opin Immunol 19: 309-314, 2007.

14 Francisco LM, Salinas VH, Brown KE, Vanguri VK, Freeman GJ, Kuchroo VK and Sharpe AH: PD-L1 regulates the development, maintenance, and function of induced regulatory T cells. J. Exp. Med 206: 3015-3029, 2009.

15 Fife BT and Bluestone JA: Control of peripheral T-cell tolerance and autoimmunity via the CTLA-4 and PD-1 pathways. Immunol Rev 224: 166-182, 2008.

16 Huang J, Zhang Y, Sheng J, Zhang H, Fang W, Zhan J, Zhou T, Chen Y, Liu L and Zhang L: The efficacy and safety of nivolumab in previously treated advanced non-small-cell lung cancer: a meta-analysis of prospective clinical trials. Onco Targets Ther 9: 5867-5874, 2016.

17 Comin-Anduix B, Escuin-Ordinas $\mathrm{H}$ and Ibarrondo FJ: Tremelimumab: research and clinical development. Onco Targets Ther 9: 1767-76, 2016. 
18 Wang J, Chmielowski B, Pellissier J, Xu R, Stevinson K and Liu FX: Cost-Effectiveness of pembrolizumab versus ipilimumab in ipilimumab-naïve patients with advanced melanoma in the United States. J Manag Care Spec Pharm 23: 184-194, 2017.

19 Martin-Liberal J, Ochoa de Olza M, Hierro C, Gros A, Rodon $\mathrm{J}$ and Tabernero $\mathrm{J}$ : The expanding role of immunotherapy. Cancer Treat Rev 54: 74-86, 2017.

20 Liu KG, Gupta S and Goel S: Immunotherapy: incorporation in the evolving paradigm of renal cancer management and future prospects. Oncotarget 10: 17313-17327, 2017.

21 Hodi FS, O’Day SJ, McDermott DF, Weber RW, Sosman JA, Haanen JB, Gonzalez R, Robert C, Schadendorf D, Hassel JC, Akerley W, van den Eertwegh AJ, Lutzky J, Lorigan P, Vaubel JM, Linette GP, Hogg D, Ottensmeier CH, Lebbé C, Peschel C, Quirt I, Clark JI, Wolchok JD, Weber JS, Tian J, Yellin MJ, Nichol GM, Hoos A and Urba WJ: Improved survival with ipilimumab in patients with metastatic melanoma. N Engl J Med 363: 711-723, 2010.

22 Brahmer JR, Tykodi SS, Chow LQ, Hwu WJ, Topalian SL, Hwu P, Drake CG, Camacho LH, Kauh J, Odunsi K, Pitot HC, Hamid O, Bhatia S, Martins R, Eaton K, Chen S, Salay TM, Alaparthy S, Grosso JF, Korman AJ, Parker SM, Agrawal S, Goldberg SM, Pardoll DM, Gupta A and Wigginton JM: Safety and activity of anti-PD-L1 antibody in patients with advanced cancer. N Engl J Med 366: 2455-2465, 2012.

23 Spain L, Diem S and Larkin J: Management of toxicities of immune checkpoint inhibitors. Cancer Treat Rev 44: 51-60, 2016.

24 Wolchok JD, Hodi FS, Weber JS, Allison JP, Urba WJ, Robert C, O’Day SJ, Hoos A, Humphrey R, Berman DM, Lonberg N and Korman AJ: Development of ipilimumab: a novel immunotherapeutic approach for the treatment of advanced melanoma. Ann NY Acad Sci 1291: 1-13, 2013.

25 Wolchok JD, Hoos A, O’ Day S, Weber JS, Hamid O, Lebbé C, Maio M, Binder M, Bohnsack O, Nichol G, Humphrey R and Hodi FS: Guidelines for the evaluation of immune therapy activity in solid tumors: immune-related response criteria. Clin Cancer Res 15: 7412-7420, 2009.

26 Eisenhauer EA, Therasse P, Bogaerts J, Schwartz LH, Sargent D, Ford R, Dancey J, Arbuck S, Gwyther S, Mooney M, Rubinstein L, Shankar L, Dodd L, Kaplan R, Lacombe D and Verweij $\mathrm{J}$ : New response evaluation criteria in solid tumours: revised RECIST guideline (version 1.1). Eur J Cancer 45: 228247, 2009.

27 Teng MW, Ngiow SF, Ribas A and Smyth MJ: Classifying Cancers Based on T-cell Infiltration and PD-L1. Cancer Res 75: 2139-2145, 2015.

28 Zhang L, Conejo-Garcia JR, Katsaros D, Gimotty PA, Massobrio M, Regnani G, Makrigiannakis A, Gray $\mathrm{H}$, Schlienger K, Liebman MN, Rubin SC and Coukos G: Intratumoral $\mathrm{T}$ cells, recurrence, and survival in epithelial ovarian cancer. N Engl J Med 348: 203-213, 2003.

29 Hwang WT, Adams SF, Tahirovic E, Hagemann IS and Coukos G: Prognostic significance of tumor-infiltrating $\mathrm{T}$ cells in ovarian cancer: a meta-analysis. Gynecol Oncol 124: 192-198, 2012.

30 Curiel TJ, Coukos G, Zou L, Alvarez X, Cheng P, Mottram P, Evdemon-Hogan M, Conejo-Garcia JR, Zhang L, Burow M, Zhu Y, Wei S, Kryczek I, Daniel B, Gordon A, Myers L,
Lackner A, Disis ML, Knutson KL, Chen L and Zou W: Specific recruitment of regulatory $\mathrm{T}$ cells in ovarian carcinoma fosters immune privilege and predicts reduced survival. Nat Med 10: 942-949, 2004.

31 Sato E, Olson SH, Ahn J, Bundy B, Nishikawa H, Qian F, Jungbluth AA, Frosina D, Gnjatic S, Ambrosone C, Kepner J, Odunsi T, Ritter G, Lele S, Chen YT, Ohtani H, Old LJ and Odunsi K: Intraepithelial CD8+ tumor-infiltrating lymphocytes and a high $\mathrm{CD}^{+} /$regulatory $\mathrm{T}$ cell ratio are associated with favorable prognosis in ovarian cancer. Proc Natl Acad Sci USA 102: 18538-18543, 2005.

32 Vermeij R, de Bock GH, Leffers N, Ten Hoor KA, Schulze U, Hollema H, van der Burg SH, van der Zee AG, Daemen T and Nijman HW: Tumor-infiltrating cytotoxic T lymphocytes as independent prognostic factor in epithelial ovarian cancer with wilms tumor protein 1 overexpression. J Immunother 34: 516523, 2011.

33 Bachmayr-Heyda A, Aust S, Heinze G, Polterauer S, Grimm C, Braicu EI, Sehouli J, Lambrechts S, Vergote I, Mahner S, Pils D, Schuster E, Thalhammer T, Horvat R, Denkert C, Zeillinger R and Castillo-Tong DC: Prognostic impact of tumor infiltrating $\mathrm{CD} 8{ }^{+} \mathrm{T}$ cells in association with cell proliferation in ovarian cancer patients - a study of the OVCAD consortium. BMC Cancer 13: 422, 2013.

34 Hamanishi J, Mandai M, Iwasaki M, Okazaki T, Tanaka Y, Yamaguchi K, Higuchi T, Yagi H, Takakura K, Minato N, Honjo T and Fujii S: Programmed cell death 1 ligand 1 and tumor-infiltrating $\mathrm{CD} 8+\mathrm{T}$ lymphocytes are prognostic factors of human ovarian cancer. Proc Natl Acad Sci USA 104: 3360$3365,2007$.

35 Maine CJ, Aziz NH, Chatterjee J, Hayford C, Brewig N, Whilding L, George AJ and Ghaem-Maghami S:Programmed death ligand-1 over-expression correlates with malignancy and contributes to immune regulation in ovarian cancer. Cancer Immunol Immunother 63: 215-224, 2014.

36 Darb-Esfahani S, Kunze CA, Kulbe H, Sehouli J, Wienert S, Lindner J, Budczies J, Bockmayr M, Dietel M, Denkert C, Braicu I and Jöhrens K: Prognostic impact of programmed cell death-1 (PD-1) and PD-ligand 1 (PD-L1) expression in cancer cells and tumor-infiltrating lymphocytes in ovarian high grade serous carcinoma. Oncotarget 7: 1486-1499, 2016.

37 Hamanishi J, Mandai M and Konishi I: Immune checkpoint inhibition in ovarian cancer. Int Immunol 28: 339-348, 2016.

38 Webb JR, Milne K, Kroeger DR and Nelson BH: PD-L1 expression is associated with tumor-infiltrating $\mathrm{T}$ cells and favorable prognosis in high-grade serous ovarian cancer. Gynecol Oncol 141: 293-302, 2016.

39 Hamanishi J, Mandai M, Ikeda T, Minami M, Kawaguchi A, Murayama T, Kanai M, Mori Y, Matsumoto S, Chikuma S, Matsumura N, Abiko K, Baba T, Yamaguchi K, Ueda A, Hosoe Y, Morita S, Yokode M, Shimizu A, Honjo T and Konishi I: Safety and antitumor activity of anti-PD- 1 antibody, nivolumab, in patients with platinum- resistant ovarian cancer. J Clin Oncol 33: 4015-4022, 2015.

40 Varga A, Piha-Paul SA, Ott PA, Mehnert JM, Berton-Rigaud D, Johnson EA, Cheng JD, Yuan S, Rubin EH and Matei DE: Antitumor activity and safety of pembrolizumab in patients (pts) with PD-L1 positive advanced ovarian cancer: Interim results from a phase Ib study. J Clin Oncol 33: abstr 5510, 2015 . 
41 Disis ML, Patel MR, Pant S, Hamilton EP, Lockhart AC, Kelly K, Beck JT, Gordon MS, Weiss GJ, Taylor MH, Chaves J, Mita AC, Kevin M, Chin KM, von Heydebreck A, Cuillerot JM and Gulley JL: Avelumab (MSB0010718C; anti-PD- L1) in patients with recurrent/refractory ovarian cancer from the JAVELIN Solid Tumor phase Ib trial: Safety and clinical activity. J Clin Oncol 34: abstr 5533, 2016.

42 Wiegand KC, Shah SP, Al-Agha OM, Zhao Y, Tse K, Zeng T, Senz J, McConechy MK, Anglesio MS, Kalloger SE, Yang W, Heravi-Moussavi A, Giuliany R, Chow C, Fee J, Zayed A, Prentice L, Melnyk N, Turashvili G, Delaney AD, Madore J, Yip S, McPherson AW, Ha G, Bell L, Fereday S, Tam A, Galletta L, Tonin PN, Provencher D, Miller D, Jones SJ, Moore RA, Morin GB, Oloumi A, Boyd N, Aparicio SA, Shih IeM, Mes-Masson AM, Bowtell DD, Hirst M, Gilks B, Marra MA and Huntsman DG: ARID1A mutations in endometriosisassociated ovarian carcinomas. N Engl J Med 363: 1532-1543, 2010.

43 Ayhan A, Mao TL, Seckin T, Wu CH, Guan B, Ogawa H, Futagami M, Mizukami H, Yokoyama Y, Kurman RJ and ShihIe M: Loss of ARID1A expression is an early molecular event in tumor progression from ovarian endometriotic cyst to clear cell and endometrioid carcinoma. Int J Gynecol Cancer 22: 13101315,2012

44 Jones S, Wang TL, Shih IeM, Mao TL, Nakayama K, Roden R, Glas R, Slamon D, Diaz LA Jr, Vogelstein B, Kinzler KW, Velculescu VE and Papadopoulos N: Frequent mutations of chromatin remodeling gene ARID1A in ovarian clear cell carcinoma. Science 330: 228-231, 2010.

45 Yamamoto S, Tsuda H, Takano M, Tamai S and Matsubara O: Loss of ARID1A protein expression occurs as an early event in ovarian clear-cell carcinoma development and frequently coexists with PIK3CA mutations. Mod Pathol 25: 615-624, 2012.

46 Xiao W, Awadallah A and Xin W: Loss of ARID1A/BAF250a expression in ovarian endometriosis and clear cell carcinoma. Int J Clin Exp Pathol 5: 642-650, 2012.

47 Katagiri A, Nakayama K, Rahman MT, Rahman M, Katagiri H, Nakayama N, Ishikawa M, Ishibashi T, Iida K, Kobayashi H, Otsuki Y, Nakayama S and Miyazaki K: Loss of ARID1A expression is related to shorter progression-free survival and chemoresistance in ovarian clear cell carcinoma. Mod Pathol 25: 282-288, 2012.

48 Gadducci A, Lanfredini N and Tana R: Novel insights on the malignant transformation of endometriosis into ovarian carcinoma. Gynecol Endocrinol 30: 612-617, 2014.

49 Friedlander ML, Russell K, Millis S, Gatalica Z, Bender R and Voss A: Molecular profiling of clear cell ovarian cancers: Identifying potential treatment targets for clinical trials. Int J Gynecol Cancer 26: 648-654, 2016.

50 Lastwika KJ, Wilson W 3rd, Li QK, Norris J, Xu H, Ghazarian SR, Kitagawa H, Kawabata S, Taube JM, Yao S, Liu LN, Gills JJ and Dennis PA: Control of PD-L1 expression by oncogenic activation of the AKT-mTOR pathway in non-small cell lung cancer. Cancer Res 76: 227-238, 2016.

51 Hodi FS, Butler M, Oble DA, Seiden MV, Haluska FG, Kruse A, Macrae S, Nelson M, Canning C, Lowy I, Korman A, Lautz D, Russell S, Jaklitsch MT, Ramaiya N, Chen TC, Neuberg D, Allison JP, Mihm MC and Dranoff G: Immunologic and clinical effects of antibody blockade of cytotoxic $\mathrm{T}$ lymphocyte- associated antigen 4 in previously vaccinated cancer patients. Proc Natl Acad Sci USA 105: 3005-3010, 2008.

52 NCT01611558: Phase II Study of Ipilimumab Monotherapy in Recurrent Platinum- sensitive Ovarian Cancer - Study Results. https://clinicaltrials.gov/ct2/show/results/NCT01611558. Accessed 24 May 2016.

53 Topalian SL, Hodi FS, Brahmer JR, Gettinger SN, Smith DC, McDermott DF, Powderly JD, Carvajal RD, Sosman JA, Atkins MB, Leming PD, Spigel DR, Antonia SJ, Horn L, Drake CG, Pardoll DM, Chen L, Sharfman WH, Anders RA, Taube JM, McMiller TL, Xu H, Korman AJ, Jure-Kunkel M, Agrawal S, McDonald D, Kollia GD, Gupta A, Wigginton JM and Sznol M: Safety, activity, and immune correlates of antiPD-1 antibody in cancer. N Engl J Med 366: 2443-2454, 2012.

54 Xiao Y and Freeman GJ: The microsatellite instable subset of colorectal cancer is a particularly good candidate for checkpoint blockade immunotherapy. Cancer Discov 5: 16-18, 2015.

55 Le DT, Uram JN, Wang H, Bartlett BR, Kemberling H, Eyring AD, Skora AD, Luber BS, Azad NS, Laheru D, Biedrzycki B, Donehower RC, Zaheer A, Fisher GA, Crocenzi TS, Lee JJ, Duffy SM, Goldberg RM, de la Chapelle A, Koshiji M, Bhaijee F, Huebner T, Hruban RH, Wood LD, Cuka N, Pardoll DM, Papadopoulos N, Kinzler KW, Zhou S, Cornish TC, Taube JM, Anders RA, Eshleman JR, Vogelstein B and Diaz LA Jr.: PD-1 Blockade in Tumors with Mismatch-Repair Deficiency. N Engl J Med 372: 2509-2520, 2015

56 Hussein YR, Weigelt B, Levine DA, Schoolmeester JK, Dao LN, Balzer BL, Liles G, Karlan B, Kobel M, Lee CH and Soslow RA: Clinicopathological analysis of endometrial carcinomas harboring somatic POLE exonuclease domain mutations. Mod Pathol 28: 505-514, 2015.

57 Strickland KC, Howitt BE, Shukla SA, Rodig S, Ritterhouse LL, Liu JF, Garber JE, Chowdhury D, Wu CJ, D'Andrea AD, Matulonis UA and Konstantinopoulos PA: Association and prognostic significance of BRCA1/2-mutation status with neoantigen load, number of tumor-infiltrating lymphocytes and expression of PD-1/PD-L1 in high grade serous ovarian cancer. Oncotarget 7: 13587-13598, 2016.

58 McAlpine JN, Porter H, Köbel M, Nelson BH, Prentice LM, Kalloger SE, Senz J, Milne K, Ding J, Shah SP, Huntsman DG and Gilks CB: BRCA1 and BRCA2 mutations correlate with TP53 abnormalities and presence of immune cell infiltrates in ovarian high-grade serous carcinoma. Mod Pathol 25: 740-750, 2012.

59 Mittica G, Genta S, Aglietta M and Valabrega G: Immune checkpoint inhibitors: a new opportunity in the treatment of ovarian cancer? Int J Mol Sci 17: 1169, 2016.

60 Strickland K, Howitt BE, Rodig SJ, Matulonis UA and Konstantinopoulos P: Immunogenicity of clear cell ovarian cancer: Association with ARID1A loss, microsatellite instability and endometriosis. J Clin Oncol 34: abstr 5514, 2016.

61 Bokhman JV: Two pathogenetic types of endometrial carcinoma. Gynecol Oncol 15: 10-17, 1983.

62 Matias-Guiu X, Catasus L, Bussaglia E, Lagarda H, Garcia A, Pons C, Muñoz J, Argüelles R, Machin P and Prat J: Molecular pathology of endometrial hyperplasia and carcinoma. Hum Pathol 32: 569-577, 2001

63 Prat J, Gallardo A, Cuatrecasas M and Catasús L: Endometrial carcinoma: pathology and genetics. Pathology 39: 72-87, 2007. 
64 Moreno-Bueno G, Sánchez-Estévez C, Cassia R, RodríguezPerales S, Díaz-Uriarte R, Domínguez O, Hardisson D, Andujar M, Prat J, Matias-Guiu X, Cigudosa JC and Palacios J: Differential gene expression profile in endometrioid and nonendometrioid endometrial carcinoma: STK15 is frequently overexpressed and amplified in nonendometrioid carcinomas. Cancer Res 63: 5697-702, 2003.

65 Santin AD, Bellone S, Van Stedum S, Bushen W, Palmieri M, Siegel ER, De Las Casas LE, Roman JJ, Burnett A and Pecorelli S: Amplification of c-erbB2 oncogene: a major prognostic indicator in uterine serous papillary carcinoma. Cancer 104: 1391-1397, 2005.

66 Catasus L, Gallardo A, Cuatrecasas M and Prat J: PIK3CA mutations in the kinase domain (exon 20) of uterine endometrial adenocarcinomas are associated with adverse prognostic parameters. Mod Pathol 21: 131-139, 2008.

67 Yalta T, Atay L, Atalay F, Caydere M, Gonultas M and Ustun $\mathrm{H}$ : E-cadherin expression in endometrial malignancies: comparison between endometrioid and non-endometrioid carcinomas. J Int Med Res 37: 163-168, 2009.

68 Hayes MP, Wang H, Espinal-Witter R, Douglas W, Solomon GJ, Baker SJ and Ellenson LH: PIK3CA and PTEN mutations in uterine endometrioid carcinoma and complex atypical hyperplasia. Clin Cancer Res 12: 5932-5935, 2006.

69 Mutter GL, Lin MC, Fitzgerald JT, Kum JB, Baak JP, Lees JA, Weng LP and Eng C: Altered PTEN expression as a diagnostic marker for the earliest endometrial precancers. J Natl Cancer Inst 92: 924-930, 2000.

70 Lax SF, Kendall B, Tashiro H, Slebos RJ and Hedrick L:The frequency of p53, K-ras mutations, and microsatellite instability differs in uterine endometrioid and serous carcinoma: evidence of distinct molecular genetic pathways. Cancer 88: 814-824, 2000.

71 Murali R, Soslow RA and Weigelt B: Classification of endometrial carcinoma: more than two types Lancet Oncol 15: e268-278, 2014.

72 Cancer Genome Atlas Research Network, Kandoth C, Schultz N, Cherniack AD, Akbani R, Liu Y, Shen H, Robertson AG, Pashtan I, Shen R, Benz CC, Yau C, Laird PW, Ding L, Zhang W, Mills GB, Kucherlapati R, Mardis ER and Levine DA: Integrated genomic characterization of endometrial carcinoma. Nature 497: 67-73, 2013.

73 Pursell ZF and Kunkel TA: DNA polymeras epsilon:polymerase of unusual size (and complexity). Prog Nucleic Acid Res Mol Biol 82: 101-145, 2008.

74 Church DN, Briggs SE, Palles C, Domingo E, Kearsey SJ, Grimes JM, Gorman M, Martin L, Howarth KM, Hodgson SV, NSECG Collaborators, Kaur K, Taylor J and Tomlinson IP: DNA polymerase $\varepsilon$ and $\delta$ exonuclease domain mutations in endometrial cancer. Hum Mol Genet 22: 2820-2828, 2013.

75 Hussein YR, Weigelt B, Levine DA, Schoolmeester JK, Dao LN, Balzer BL, Liles G, Karlan B, Köbel M, Lee CH and Soslow RA: Clinicopathological analysis of endometrial carcinomas harboring somatic POLE exonuclease domain mutations. Mod Pathol 28: 505-514, 2015.

76 Church DN, Stelloo E, Nout RA, Valtcheva N, Depreeuw J, ter Haar N, Noske A, Amant F, Tomlinson IP, Wild PJ, Lambrechts D, Jürgenliemk-Schulz IM, Jobsen JJ, Smit VT, Creutzberg CLand Bosse T:Prognostic significance of POLE proofreading mutations in endometrial cancer. J Natl Cancer Inst 107: 402, 2014.
77 Meng B, Hoang LN, McIntyre JB, Duggan MA, Nelson GS, Lee $\mathrm{CH}$ and Köbel M: POLE exonuclease domain mutation predicts long progression free survival in grade 3 endometrioid carcinoma of the endometrium. Gynecol Oncol 134: 15-19, 2014.

78 Stelloo E, Bosse T, Nout RA, MacKay HJ, Church DN, Nijman HW, Leary A, Edmondson RJ, Powell ME, Crosbie EJ, Kitchener HC, Mileshkin L, Pollock PM, Smit VT and Creutzberg CL: Refining prognosis and identifying targetable pathways for high-risk endometrial cancer; a TransPORTEC initiative. Mod Pathol 28: 836-844, 2015.

79 McConechy MK, Talhouk A, Leung S, Chiu D, Yang W, Senz J, Reha-Krantz LJ, Lee CH, Huntsman DG, Gilks CB and McAlpine JN: Endometrial Carcinomas with POLE Exonuclease Domain Mutations Have a Favorable Prognosis.Clin Cancer Res 22: 2865-2867, 2016.

80 Wira CR, Fahey JV, Ghosh M, Patel MV, Hickey DK and Ochiel DO: Sex hormone regulation of innate immunity in the female reproductive tract: the role of epithelial cells in balancing reproductive potential with protection against sexually transmitted pathogens. Am J Reprod Immunol 63: 544-565, 2010.

81 Vanderstraeten A, Tuyaerts S and Amant F: The immune system in the normal endometrium and implications for endometrial cancer development. J Reprod Immunol 109: 7-16, 2015.

82 de Jong RA, Leffers N, Boezen HM, ten Hoor KA, van der Zee AG, Hollema $\mathrm{H}$ and Nijman HW: Presence of tumor-infiltrating lymphocytes is an independent prognostic factor in type I and II endometrial cancer. Gynecol Oncol 114: 105-110, 2009.

83 Yamagami W, Susumu N, Tanaka H, Hirasawa A, Banno K, Suzuki N, Tsuda H, Tsukazaki K and Aoki D: Immunofluorescence-detected infiltration of $\mathrm{CD}^{+}{ }^{+} \mathrm{FOXP} 3^{+}$regulatory $\mathrm{T}$ cells is relevant to the prognosis of patients with endometrial cancer. Int J Gynecol Cancer 21: 1628-1634, 2011.

84 Herzog T, Arguello D, Reddy S and Gatalica Z: PD-1 and PDL1 expression in 1599 gynecological malignancies - implications for immunotherapy. Gynecol Oncol 137: 204-205, 2015.

85 Vanderstraeten A, Luyten C, Verbist G, Tuyaerts S and Amant F: Mapping the immunosuppressive environment in uterine tumors: implications for immunotherapy. Cancer Immunol Immunother 63: 545-557, 2014.

86 Howitt BE, Shukla SA, Sholl LM, Ritterhouse LL, Watkins JC, Rodig S, Stover E, Strickland KC, D'Andrea AD, Wu CJ, Matulonis UA and Konstantinopoulos PA: Association of Polymerase e-mutated and microsatellite-instable endometrial cancers with neoantigen load, number of tumor-infiltrating lymphocytes, and expression of PD-1 and PD-L1. JAMA Oncol 1: 1319-1323, 2015.

87 Longoria TC and Eskander RN: Immunotherapy in endometrial cancer - an evolving therapeutic paradigm. Gynecol Oncol Res Pract 2: 11, 2015.

88 Gargiulo P, Della Pepa C, Berardi S, Califano D, Scala S, Buonaguro L, Ciliberto G, Brauchli P and Pignata S:Tumor genotype and immune microenvironment in POLE-ultramutated and MSI-hypermutated Endometrial Cancers: New candidates for checkpoint blockade immunotherapy? Cancer Treat Rev 48: 61-68, 2016

89 Santin AD, Bellone S, Buza N, Choi J, Schwartz PE, Schlessinger J and Lifton RP: Regression of chemotherapyresistant polymerase $\varepsilon$ (POLE) ultra-mutated and MSH6 hypermutated endometrial tumors with nivolumab. Clin Cancer Res 22: $5682-5687,2016$. 
90 Monk BJ , Sill MW, McMeekin DS, Cohn DE, Ramondetta LM, Boardman CH, Benda J and Cella D: Phase III trial of four cisplatin-containing doublet combinations in stage IVB, recurrent, or persistent cervical carcinoma: a Gynecologic Oncology Group study. J Clin Oncol 27: 4649-4655, 2009.

91 Tewari KS, Sill MW, Long HJ 3rd, Penson RT, Huang H, Ramondetta LM, Landrum LM, Oaknin A, Reid TJ, Leitao MM, Michael HE and Monk BJ: Improvedsurvival with bevacizumab in advancedcervical cancer. $\mathrm{N}$ Engl J Med 370: 734-743, 2014.

92 Abu-Rustum NR, Lee S and Massad LS: Topotecan for recurrent cervical cancer after platinum-based therapy. Int $\mathrm{J}$ Gynecol Cancer 10: 285-288, 2000.

93 Muggia FM, Blessing JA, Method M, Miller DS, Johnson GA, Lee RB and Menzin A: Evaluation of vinorelbine in persistent or recurrent squamous cell carcinoma of the cervix: a Gynecologic Oncology Group study. Gynecol Oncol 92: 639643, 2004.

94 Schilder RJ, Blessing $\mathrm{J}$ and Cohn DE: Evaluation of gemcitabine in previously treated patients with non-squamous cell carcinoma of the cervix: a phase II study of the Gynecologic Oncology Group. Gynecol Oncol 96: 103-107, 2005.

95 Miller DS, Blessing JA, Bodurka DC, Bonebrake AJ and Schorge JO: Evaluation of pemetrexed (Alimta, LY231514) as second line chemotherapy in persistent or recurrent carcinoma of the cervix: a phase II study of the Gynecologic Oncology Group. Gynecol Oncol 110: 65-70, 2008.

96 Garcia AA, Blessing JA, Darcy KM, Lenz HJ, Zhang W, Hannigan E and Moore DH: Phase II clinical trial of capecitabine in the treatment of advanced, persistent or recurrent squamous cell carcinoma of the cervix with translational research: a gynecologic oncology group study. Am J Clin Oncol 30: 428-431, 2007.

97 Garcia AA, Blessing JA, Vaccarello L and Roman LD: Phase II clinical trial of docetaxel in refractory squamous cell carcinoma of the cervix: a Gynecologic Oncology Group Study. Am J Clin Oncol 30: 428-431, 2007.

98 Minion LE, Chase DM, Farley JH, Willmott LJ and Monk BJ: Safety and efficacy of salvage nano-particle albumin bound paclitaxel in recurrent cervical cancer: a feasibility study. Gynecol Oncol Res Pract 3: 4, 2016.

99 Tewari KS and Monk BJ: New strategies in cervical cancer: from angiogenesis blockade to immunotherapy Clin Cancer Res 20: 5349-5358, 2014.

100 Longoria TC and Tewari KS: Pharmacologic management of advancedcervical cancer: antiangiogenesis therapy and immunotherapeutic considerations. Drugs 75: 1853-1865, 2015
101 Boussios S, Seraj E, Zarkavelis G, Petrakis D, Kollas A, Kafantari A, Assi A, Tatsi K, Pavlidis N and Pentheroudakis G: Management of patients with recurrent/advanced cervical cancer beyond first line platinum regimens: Where do we stand? A literature review. Crit Rev Oncol Hematol 108: 164174, 2016.

102 Lee SJ, Yang A, Wu TC and Hung CF: Immunotherapy for human papillomavirus-associated disease and cervical cancer: review of clinical and translational research J Gynecol Oncol 27: e51, 2016

103 Karim R, Jordanova ES, Piersma SJ, Kenter GG, Chen L, Boer JM, Melief CJ and van der Burg SH: Tumor-expressed B7-H1 and B7-DC in relation to PD-1+ T-cell infiltration and survival of patients with cervical carcinoma. Clin Cancer Res 15: 63416347, 2009.

104 Yang W, Song Y, Lu YL, Sun JZ and Wang HW: Increased expression of programmed death (PD)-1 and its ligand PD-L1 correlates with impaired cell-mediated immunity in high-risk human papillomavirus-related cervical intraepithelial neoplasia. Immunology 139: 513-522, 2013.

105 Mezache L, Paniccia B, Nyinawabera A and Nuovo GJ: Enhanced expression of PD L1 in cervical intraepithelial neoplasia and cervical cancers. Mod Pathol 28: 1594-1602, 2015.

106 Heeren AM, Punt S, Bleeker MC, Gaarenstroom KN, van der Velden J, Kenter GG, de Gruijl TD and Jordanova ES: Prognostic effect of different PD-L1 expression patterns in squamous cell carcinoma and adenocarcinoma of the cervix. Mod Pathol 29: 753-763, 2016.

107 Chanmee T, Ontong P, Konno K and Itano N: Tumor-associated macrophages as major players in the tumor microenvironment. Cancers (Basel) 6: 1670-1690, 2014.

108 Ring KL, Pakish $\mathrm{J}$ and Jazaeri AA: Immune Checkpoint Inhibitors in the Treatment of Gynecologic Malignancies. Cancer J 22: 101-107, 2016.

109 Emens LA, Kok M and Ojalvo LS: Targeting the programmed cell death-1 pathway in breast and ovarian cancer. Curr Opin Obstet Gynecol 28: 142-147, 2016.
Received May 8, 2017

Revised May 23, 2017

Accepted June 2, 2017 